\title{
Is It Such a Big Deal? On the Cost of Journal Use in the Digital Era
}

\section{Fei Shu, Philippe Mongeon, Stefanie Haustein, Kyle Siler, Juan Pablo Alperin, and Vincent Larivière}

\begin{abstract}
Commercial scholarly publishers promote and sell bundles of journalsknown as big deals - that provide access to entire collections rather than individual journals. Following this new model, size of serial collections in academic libraries increased almost fivefold from 1986 to 2011. Using data on library subscriptions and references made for a sample of North American universities, this study provides evidence that, while big deal bundles do decrease the mean price per subscribed journal, academic libraries receive less value for their investment. We find that university researchers cite only a fraction of journals purchased by their libraries, that this fraction is decreasing, and that the cost per cited journal has increased. These findings reveal how academic publishers use product differentiation and price strategies to increase sales and profits in the digital era, often at the expense of university and scientific stakeholders.
\end{abstract}

\section{Introduction}

The creation of the journal, more than 350 years ago, changed the scholarly communication process and allowed for a more structured and regular distribution of scientific discoveries. Today, journals are more than a dissemination tool; they are also intertwined with the reward system of science. Scholars need to publish their works in what are considered to be the highest impact journals to receive professional acclaim and advancement. ${ }^{1}$ Peers read publications in journals and acknowledge relevant contributions by citing them in their own works. Access to academic journals is essential for scholars to be aware of existing research and to disseminate their own findings. ${ }^{2}$

Fei Shu is a Professor at Chinese Academy of Science and Education Evaluation (CASSE), Hangzhou Dianzi University and is an Associated Researcher at École de bibliothéconomie et des sciences de l'information, Université de Montréal, e-mail: fei.shu28@gmail.com; Philippe Mongeon is a Postdoctoral Researcher at the Center for Science and Technology Studies (CWTS), Leiden University, e-mail: p.mongeon@cwts. leidenuniv.nl; Stefanie Haustein is an Assistant Professor at School of Information Studies, University of Ottawa and is an Associated Researcher at Observatoire des Sciences et des Technologies (OST), Centre Interuniversitaire de Recherche sur la Science et la Technologie (CIRST), Université du Québec à Montréal, e-mail: stefanie.haustein@uottawa.ca; Kyle Siler is Postdoctoral Researcher at Utrecht University, e-mail: ksiler@gmail.com; Juan Pablo Alperin is an Assistant Professor at Simon Fraser University, e-mail: juan@ alperin.ca; and Vincent Larivière is an Associate Professor at École de bibliothéconomie et des sciences de l'information, Université de Montréal and is the Associate Scientific Director at Observatoire des Sciences et des Technologies (OST), Centre Interuniversitaire de Recherche sur la Science et la Technologie (CIRST), Universitédu Québec à Montréal, e-mail: vincent.lariviere@umontreal.ca. (C2018 Fei Shu, Philippe Mongeon, Stefanie Haustein, Kyle Siler, Juan Pablo Alperin, and Vincent Larivière, Attribution-NonCommercial (http://creativecommons.org/licenses/by-nc/4.0/) CC BY-NC. 
Recently, widespread financial pressures have threatened access to these journals at many universities. Since the 1990s, academic libraries have absorbed continual increases in the cost of scholarly journal subscriptions. ${ }^{3}$ The average price of U.S. academic journals has increased more than eightfold between 1984 and 2010, while the U.S. national inflation rate was only 110 percent during that same 25 -year period. ${ }^{4}$ As a result, many academic libraries, struggling with stagnant or shrinking budgets, often have no choice but to cancel some subscriptions to keep core journals of each discipline in the library collection. ${ }^{5}$ The dilemma of dramatically increasing subscription rates and budget cuts faced by modern university libraries has been dubbed the serials crisis. Librarians and scholars attribute this crisis to the greed of commercial academic publishers, criticizing them for charging horrendous subscription prices. ${ }^{6}$ Previous studies report that the average subscription price charged by commercial publishers is about three times higher than those charged by nonprofit publishers in the same discipline. ${ }^{7}$ As a result, scholarly publishing has developed into one of the most profitable industries in the world, with profit margins often exceeding 30 percent. $^{8}$

While the first scholarly journals were created by academic societies, the Victorian era saw the entry of commercial publishers into the market, whose dissemination channels were more efficient than those of scientific societies. ${ }^{9}$ Scientific societies maintained their dominance on the academic journal market prior to World War II; since then, commercial publishing houses have continually increased their market shares. ${ }^{10}$ Despite hopes for a democratization of the market with the growth of the Internet, the advent of electronic journals helped commercial publishers accelerate such price increases. As shown by Larivière et al., the top five academic publishers accounted for more than half of scholarly papers indexed in the Web of Science (WoS) in 2013-a clear increase from predigital-era levels. Such increase of commercial publishers' portfolios is due to mergers and acquisitions, as well as the creation of new journals, ${ }^{11}$ all of which contributes to increases in subscription prices. ${ }^{12}$ Using this oligopolistic market power, commercial academic publishers strategically engage in price discrimination in the journal subscription market via the creation and sale of bundled journals. ${ }^{13}$ Edlin and Rubinfeld argue that these big deals may even violate the Sherman Antitrust Act. ${ }^{14}$ Recently, the competitive practices of RELX Group (Elsevier) have been brought to the attention of the Competition and Markets Authority in the United Kingdom. ${ }^{15}$

On the other side, academic libraries play a unique role in this subscription market, contributing almost three-quarters of academic publishers' revenue. ${ }^{16}$ While librarians are rarely the end-users of journals, they serve as subscription agents-and thus as information providers and curators - to support research and teaching efforts at their institutions. ${ }^{17}$ Rising journal prices have stretched static and shrinking library budgets, often forcing cuts to subscriptions and alarming both faculty and students who have been accustomed to full access to most or all journals since the advent of big deals. ${ }^{18}$

In the academic journal market, libraries are the buyers and publishers are the sellers while scholarly journals can be considered as a special good. Each paper they publish contains unique knowledge claims without substitutes. ${ }^{19}$ This contributes to an inelastic demand for academic journals, where demand responds little to price changes. However, not all academic journals have price-inelastic demand. ${ }^{20}$ As researchers do not have the time to read all the papers relevant to their research, the reputation of the journal is generally the key selection criterion for reading and attention. ${ }^{21}$ As a result, the demand for high-impact journals (core journals) is price-inelastic, while that of low-impact journals (secondary journals) is much more elastic and price-sensitive. This provides an opportunity for academic publishers to segment the subscription market and apply different pricing strategies respectively. For instance, commercial publishers have been accused of using their market power to manipulate journal subscription prices, ${ }^{22}$ as well as practicing price 
discrimination by charging different prices for identical goods to different customers in bundle sales. ${ }^{23}$ Commercial publishers charge libraries different prices for the big deal, not based on universities' actual use of journals but rather on their capacity - or willingness - to pay, to maximize profit. ${ }^{24}$ Commercial publishers often demand price secrecy, with nondisclosure agreements (NDA) as part of these deals, which makes it difficult for universities to compare prices and negotiate. In addition to price discrimination, large commercial publishers exercise product differentiation that distinguishes a product from others to make it more attractive in the target market. ${ }^{25}$ They differentiate among journals on the basis of their quality and impact, segment journals into different groups, and apply different price strategies to each group, all in an effort to maximize profits and make it difficult for libraries enrolled in the big deal to return to individual journal-level subscriptions.

\section{Literature Review}

Most studies on scholarly publishing focus on the impact of publishers' activities on the journal subscription market, but they overlook the role of academic libraries as the consumer. ${ }^{26}$ Edlin and Rubinfeld attribute the evolution of big deals to the increasingly concentrated academic journal market in which commercial academic publishers apply price discrimination into the big deals and charge libraries different prices for the same bundle. ${ }^{27}$

Frazier states that the big deal is a dangerous game in which libraries face the all-or-nothing choice of paying whatever publishers want or giving up an indispensable resource, pointing out that academic libraries are engaged in a process in which short-term institutional benefits are achieved at the long-term expense of the academic community. ${ }^{28}$ On the other hand, Ware and Mabe insist that the big deal as well as other similar discounted packages widen researchers' access to journals and simultaneously reduce average unit costs. ${ }^{29}$

Other authors have aimed to evaluate big deals through the analysis of journal use. Blecic, Wiberley, Fiscella, Bahnmaier-Blaszczak, and Lowery investigated the library journal use as the Successful Full-Text Article Request (SFTAR) and find that 80 percent of SFTARs derive from fewer than 30 percent of the journals in big deals. ${ }^{30}$ Poynder points out that the current challenge is not the price of big deals but the cost of maintaining a scholarly publishing system that encourages overconsumption. ${ }^{31}$ McGuigan even proposes a "pay by the article" model, in which only journal articles will be purchased, based on the fact that the journal article is a container of information as opposed to the journal issue. ${ }^{32}$ However, no study has evaluated big deals through the journal use as citations received by journals, although citations could represent the actual journal use in both the predigital era and digital era.

The objective of this article is to compare journal subscriptions and actual use for American and Canadian research universities. In the predigital era, journal use was traditionally compiled in tedious reshelving exercises; with electronic publishing, these were replaced by more efficient click and download statistics. ${ }^{33}$ Citations received by a journal provide another indication of its use by the research community, as academic research builds on previous works, ${ }^{34}$ and credit is generally provided through citations as "a pellet of peer recognition." ${ }^{35}$ As the only indicator of use consistently available for print and online publication, references found in papers authored by researchers affiliated with a particular university are used in this study to measure journal use by local university communities. We investigate whether universities benefit from big deals by answering two main research questions:

1. How does the advent of the big deal affect the relationship between availability and use of journals?

2. How do big deals affect the average cost per use of journals? 


\section{Materials and Methods}

The study is based on journal subscriptions data from the Association of Research Libraries (ARL) Statistics and journal use based on journals cited in WoS. ARL is a nonprofit membership organization of 124 research libraries from the United States and Canada. ARL Statistics is a series of annual publications that describe the collections, expenditures, staffing, and service activities for ARL member institutions. Data on journal costs and usage were collected from the ARL annual survey. Since some statistics in the ARL survey - such as the Current Serials Purchased (Subscriptions), Monograph Purchased, and so on-are optional, not all research libraries report full statistics in the survey. In addition, the survey was also changed frequently; some criteria were removed, while others were added. The current study is based on the 34 university libraries consistently reported in the volumes of Current Serials Purchased between 1986 and 2011. As table 1 shows, these 34 university libraries represent academic libraries of different size and universities with various missions and levels of affluence.

\begin{tabular}{|l|c|c|c|c|}
\hline \multicolumn{5}{|c|}{ TABLE 1 } \\
Size of Collection and Expenditures for 34 University Libraries Included in \\
the Study, by Rank Order (Out Of 115) For 2010-2011
\end{tabular}




\begin{tabular}{|c|c|c|c|c|}
\hline \multicolumn{5}{|c|}{$\begin{array}{c}\text { TABLE } 1 \\
\text { Size of Collection and Expenditures for } 34 \text { University Libraries Included in } \\
\text { the Study, by Rank Order (Out Of 115) For 2010-2011 }\end{array}$} \\
\hline University & $\begin{array}{c}\text { Volumes in } \\
\text { Library }\end{array}$ & $\begin{array}{l}\text { Current } \\
\text { Serials }\end{array}$ & $\begin{array}{c}\text { Library } \\
\text { Expenditures }\end{array}$ & $\begin{array}{c}\text { Expenditures } \\
\text { on Serials }\end{array}$ \\
\hline New York & 30 & 2 & 7 & 11 \\
\hline North Carolina State & 41 & 93 & 32 & 61 \\
\hline Ohio State & 25 & 22 & 12 & 36 \\
\hline Oklahoma & 28 & 40 & 61 & 34 \\
\hline Oregon & 86 & 60 & 97 & 107 \\
\hline Purdue & 81 & 98 & 56 & 42 \\
\hline SUNY-Buffalo & 50 & 51 & 82 & 72 \\
\hline Temple & 51 & 74 & 58 & 81 \\
\hline Tennessee & 79 & 91 & 48 & 8 \\
\hline Texas A\&M & 39 & 16 & 24 & 5 \\
\hline Toronto & 4 & 30 & 2 & 1 \\
\hline Virginia Tech & 100 & 113 & 101 & 99 \\
\hline
\end{tabular}

Variables used in this paper are: Current Serials Purchased, Expenditures for Current Serials, Expenditures for Monographs, and Total Library Materials Expenditures. To account for inflation when comparing observations over different years, all expenditures were adjusted by the Consumer Price Index (CPI) and expressed using the constant 1986 U.S. dollar. In addition, we used the median instead of the mean to measure the average library expenditures as above in this paper.

We use references to each journal as an indicator of their use. Although download data would provide comprehensive information of university-level usage of journals, these data are not publicly available; and, in the case of many publishers, they cannot be shared by universities. In addition, download data cannot be obtained for the predigital era. Citation data used in this paper are based on more than 12,000 journals included in the Science Citation Index Expanded, the Social Science Citation Index, and the Arts and Humanities Citation Index of the WoS. Although Scopus offers similar bibliometric data, WoS is the only bibliometric database covering a century of citation-based indicators for all disciplines, as well as (since 1973) all authors and their institutional affiliations. ${ }^{36}$ On the other hand, Scopus data are much sparser prior to 1996. We collected all WoSindexed articles published between 1986 and 2011 by researchers affiliated with each of the 34 universities included $(n=1,719,153)$ and manually disambiguated institutional addresses. For a given university and year, a used journal is defined as one appearing in the reference list of at least one article published that year by an author affiliated with that university. Excluding references made to nonserial sources (that is, references without a volume number and an author), our dataset contains 50,523,181 references to 628,919 distinct strings in the journal field; however, this largely overestimates the actual number of cited journals, mostly because of the lack of standardization of cited journals' titles in the data and input errors. The extent of this overestimation can be grasped with a comparison to Ulrich's Periodical Directory, which contains about 300,000 records of periodicals (http://ulrichsweb.serialssolutions.com/), many of which are consumer magazines and other types of serials without much relevance to academic research. A recent study estimated the number of academic journals in Ulrich's at just 
over $70,000 .{ }^{37}$ Overestimating the number of journals used, however, is not problematic in the context of this research, since we are interested in the citation trends rather than the raw number of journals used. Hence, while our publication data does not cover the entire research output of each university-such as books, grey literature and non-indexed journals -it does provide a comprehensive list of the cited journals, as the articles cite a much broader set of journals than those indexed in WoS (in other words, nonsource items).

To restrict our data to references made to scholarly journals and remove duplication as much as possible, a basic filter was done by removing all titles beginning with the string " $\mathrm{P}$," which is the form used in the WoS for conference proceedings (for example: $\mathrm{P}$ C JAP SOC APPL PHY = Proceedings of the Conference of the Japan Society of Applied Physics), and all titles beginning with a number (example: 24 BIENN C CARB CHAR = 24th Biennial Conference on Carbon, Charleston, July 1999, American Carbon Society). We also removed the titles ending with numbers or with the string " $S$ " followed or not by a number, as these are generally journals or conferences' supplement number that cause many duplicates (example: AM J KIDNEY DIS S2=American Journal of Kidney Diseases Supplement 2). Figure 1 shows the evolution of the total number of distinct journals cited by at least one of the 34 universities over time before and after this basic cleaning. It also shows changes in the number of cited journals when different inclusion thresholds are used. For instance, the "top 99\% after basic cleaning" line shows the number of distinct journals that account for 99 percent of all references made in a given year. We find similar trends for every threshold, indicating that, while the volume is amplified by the duplication, the upward trends are not due to the duplication of the journal titles, but to the increasing diversity of journals cited by researchers affiliated to the universities included in this study.

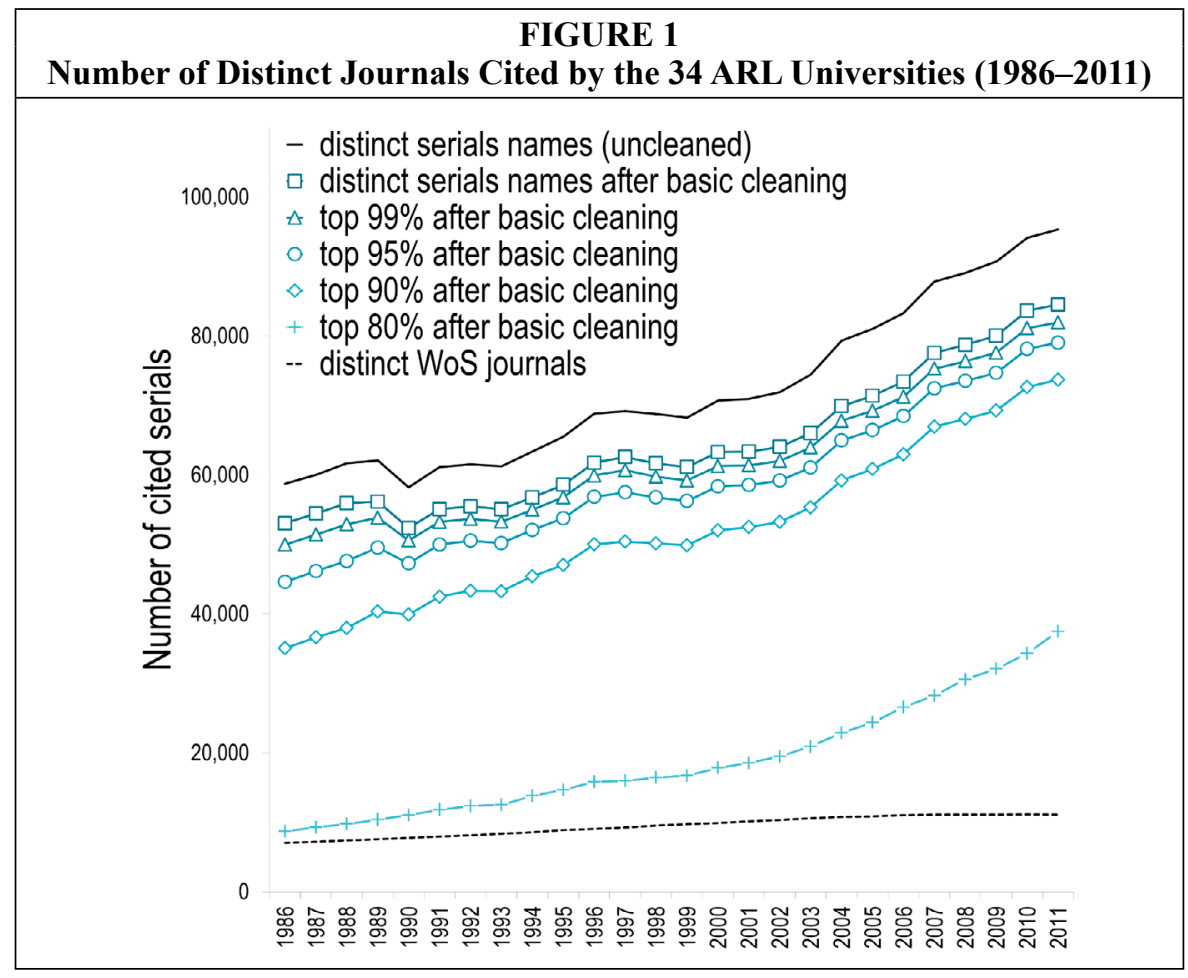


We compiled two indicators: 1) the cited journals vs. journal subscriptions ratio, which is obtained by dividing the number of journals cited by scholars from a given institution by the number of journals to which that institution is subscribed; and 2) the average cost per cited journal, obtained by dividing the total expenditures in journal subscription in a given institution by the number of journals cited by scholars of the same institution. The former indicates the proportion of the serials collection that is used (that is to say, cited) by scholars, while the latter measures the average cost of these journals. Since the investigation covers a period of 26 years, we also take inflation as Consumer Price Index (CPI) into account when calculating expenditures and costs as we mentioned above.

\section{Results}

In 1986, the median amount spent for journals by the 34 university libraries was $\$ 1,420 \mathrm{~K}$, ranging from $\$ 660 \mathrm{~K}$ (Colorado State) to $\$ 2,475 \mathrm{~K}$ (Toronto). Serials expenditures increased by 223 percent during the 25 following years and, in 2011, the median amount was $\$ 3,661 \mathrm{~K}$, ranging from $\$ 1,743 \mathrm{~K}$ (California, Riverside) to $\$ 7,840 \mathrm{~K}$ (Columbia) (see figure 2). In comparison, monograph expenditures decreased by 21 percent, which has affected disciplines that rely on books more heavily, such as social sciences and humanities. On the whole, the ratio of serials expenditures to the total library materials expenditures increased from 53 percent in 1986 to 73 percent in 2011 on average with a corollary decrease in expenditures on other types of materials, such as monographs.

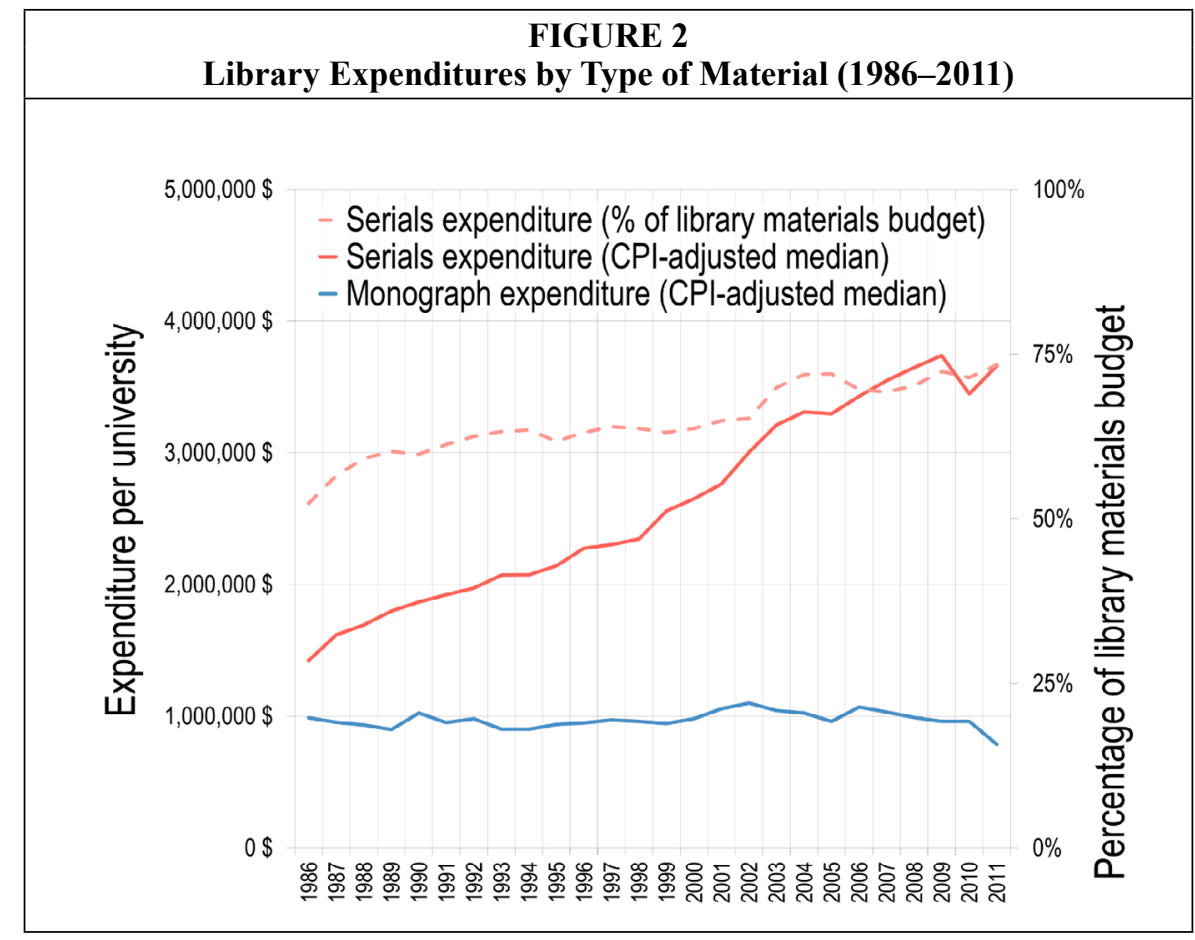

ARL Statistics reveals a clear change in libraries' journal subscriptions around 2000. In 1986, the number of journals to which the 34 libraries subscribed ranged from 8,445 (Colorado State) to 32,401 (Toronto), with a median of 15,617. Figure 3 shows that, after slightly decreasing to 13,682 in 2001 , the median number of journals increased by 503 


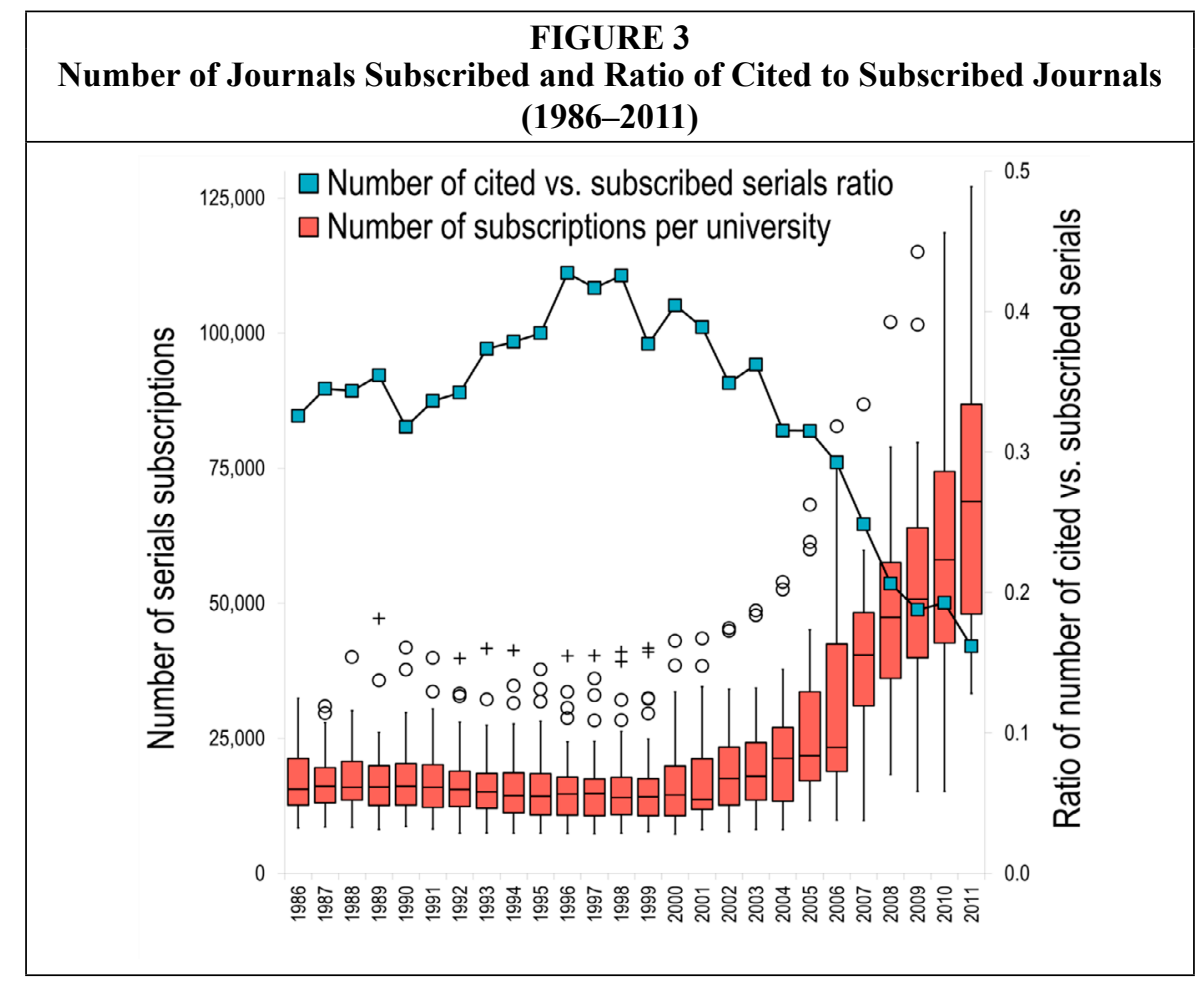

\section{FIGURE 4}

Cost of Journal Subscription, Cited Journals, and All Journals (1986-2011)

$2,500 \$$ Average cost (CPI-adjusted) per number of cited journals

- Average cost (CPI-adjusted) per number of subscribed journals

$2,000 \$$

$1,500 \$$

$1,000 \$$

$500 \$$

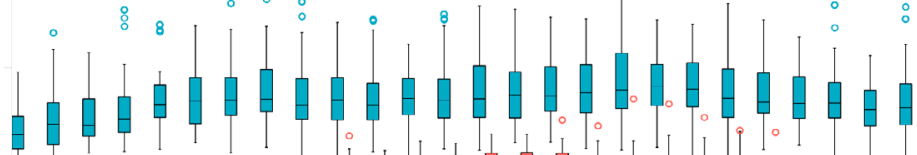

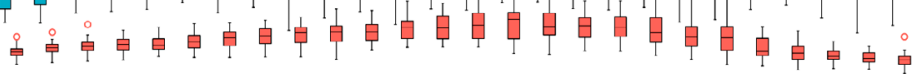

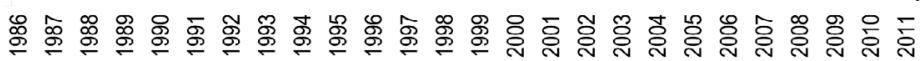


percent during the subsequent 10 years, reaching 68,837 in 2011 and ranging from 33,292 (Maryland) to 127,085 (New York). However, a different trend is observed when one considers only cited journals. The median number of journals cited by scholars affiliated with the 34 universities doubled between 1986 and 2011, but the number of journal subscriptions increased fourfold. The median cited journal ratio peaked at 43 percent in 1996 but dropped down to 16 percent in 2011 (see figure 3). In 2011, the cited journal ratio per university ranged from 4 percent (Howard) to 47 percent (Maryland).

The average cost of journal subscriptions has both risen and fallen over the period studied. As shown in figure 4, the median cost of a journal subscription for the 34 libraries went from $\$ 90$ in 1986 to $\$ 198$ in 2000 and then decreased by 68 percent, down to $\$ 64$ in 2011, which was even lower than the median in 1986 (\$90). Meanwhile, the average cost of cited journals continually increased from $\$ 280$ in 1986 to $\$ 439$ in 2005, then decreased to $\$ 363$ in 2011 - which nonetheless represents a 30 percent increase from 1986.

These results show that the widespread digitization of knowledge has increased libraries' collections by providing access to more journals at a lower average price. However, many of these added journals are having little apparent impact on the research activities of scholars, as indicated by their lack of citations. This contributes to higher costs per periodical used as the numerator increases while the denominator stays the same.

\section{Discussion}

On the whole, our results provide evidence of a radical change in the academic journal subscription market around 2000, when big deals of bundled journals were introduced by commercial publishers. ${ }^{38}$ These changes are influenced by interplay of suppliers (publishers), consumers (academic libraries representing researchers and scholars), and the product (journals) in the era of digital knowledge.

Prior to the 2000s, the academic journal subscription market resembled a traditional competitive market as portrayed in figure 5. The supply curve and the demand curve cross at the equilibrium point E; publishers sell $Q$ serials to academic libraries at the average price $P$. The average cost of serials for publishers is $\mathrm{P}^{\prime}$ when selling $Q$ serials. The area of PEQO represents the revenue of serials sales while the area of PEE' $\mathrm{P}^{\prime}$ represents the profits. The cost of an academic journal consisted of the fixed cost (first-copy) including manuscript preparation and editing, marketing, staff salaries as well as other operation costs. Variable costs included printing, handling, and shipping. Since the first-copy cost is fixed, the marginal cost only includes the extra cost of printing, handling, and shipping. As shown in figure 5, a marginal cost below the average cost pulls the average cost down, and a marginal cost above the average cost pulls the average cost up.

Since the 2000s, the use of electronic journals has been introduced and promoted by academic publishers. Journals in electronic format eliminate some production costs, including costs for printing, handling, and shipping. Further, while print journals can be considered as rivalrous goods - which cannot be possessed by more than one consumer at a time-electronic journals are nonrivalrous goods, which can be used simultaneously by more than one consumer at a time. ${ }^{39}$ This diminishes marginal production costs to or near zero for electronic journals. ${ }^{40}$ As figure 6 shows, the decreasing marginal cost pulls the average cost (per title) down as sales volume increases. This leads suppliers (publishers) to be willing to sell more goods (journals) at a lower price, which remains higher than the decreasing average cost. As a result, publishers supply academic journals according to the demand curve of journals, which allows them to determine bundles' prices on libraries' capacity to pay. In figure 6, even if publishers 


\section{FIGURE 5}

Supply Demand Curves of Journal Subscription Market (1986-2000)

S: Supply; D: Demand; AC: Average Cost; MC: Marginal Cost; Revenue = area of PEQO; Profit $=$ area of PEE'P'

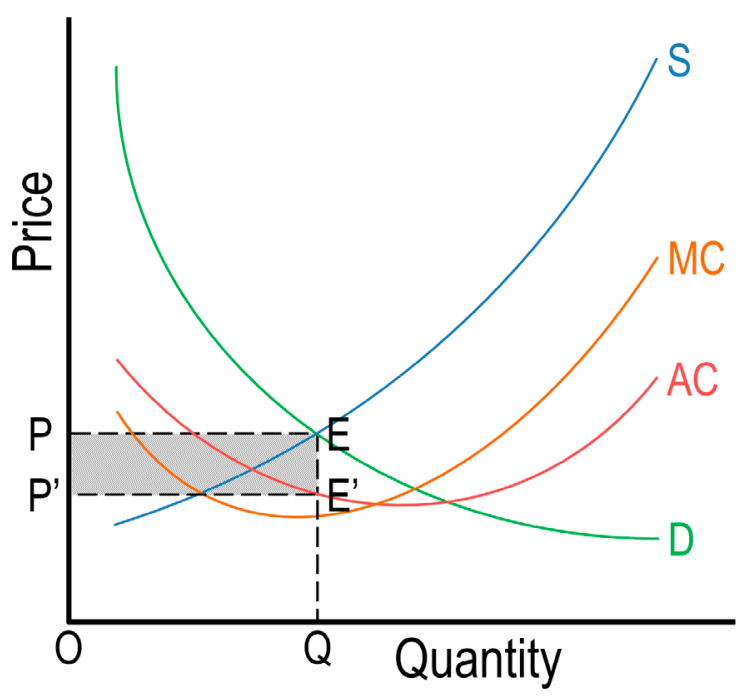

\section{FIGURE 6}

Supply Demand Curves of Journal Subscription Market (2000-onward)

D: Demand; AC: Average Cost; MC: Marginal Cost; Revenue = area of PEQO; Profit = area of PEE'P'

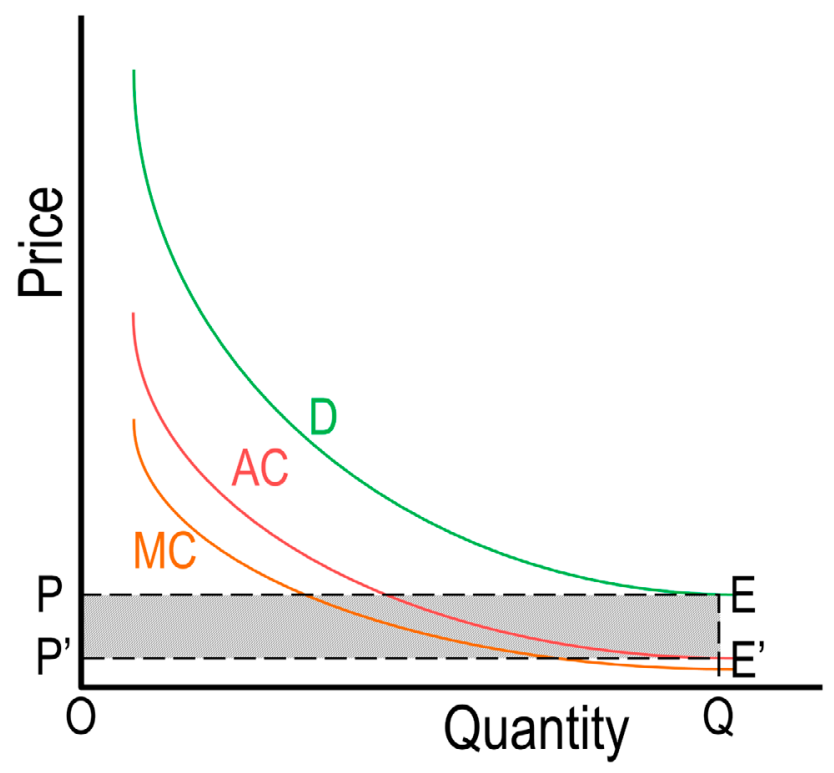


sell more serials to academic libraries at a lower price $\mathrm{P}$, compared with the value of $\mathrm{P}$ in figure 5, they could earn more profits represented as the area of PEE'P' because of an increase in demand, which is larger than the area of $\mathrm{PEE}^{\prime} \mathrm{P}^{\prime}$ in figure 5. So academic publishers increase sales volume and profits by selling additional journals with no use or little use at the maximum price libraries are willing to pay.

Since the 1970s, the academic publishing market has moved to an increasingly oligopolistic structure, in which large commercial publishers increased their shares by means of mergers and acquisitions. ${ }^{41}$ Given their oligopolistic position, these publishers exploited inelastic demand for academic journals to increase prices. Although the shift from print to electronic publishing started in the mid-1990s, print remained the main format of academic journals until the mid-2000s, with academic libraries performing selected journal subscriptions based on impact factors or on their knowledge of faculty needs. ${ }^{42}$ Hence, from 1986 to 1999 , the 34 libraries included in this analysis roughly subscribed to the same number of journals, and about 20 to 30 percent of those journals were cited by their scholars at least once. With market control acquired and consolidated via mergers and acquisitions, large commercial publishers capitalized on the technologies made possible by the digital era. Publishers devised the bundles, which purpose is to sell journals that libraries traditionally would not subscribe to. Demand for secondary journals is relatively elastic; thus, lower prices lead to increased demand accordingly. Publishers bundled core journals with secondary journals and charged bundle prices that are slightly higher than what libraries had to pay to subscribe to core journals only.

These big deal bundles were seen as attractive for libraries who could provide access to significantly more journals with seemingly little $(10 \%-15 \%)$ additional cost, thus decreasing the average cost of journal subscriptions. ${ }^{43}$ As a result, the big deals increased the size of libraries' serials collection, while publishers generated more revenues and profit from the bundles. However, the university's community did not receive corresponding value from these deals, since their users did not cite many of the extra journals their library subscribes to (the cited journal ratio decreased by half after 2000). Indeed, the average cost of cited journals was stable, but the ratio of cited journals to all subscribed journals decreased 61 percent from 2000 to 2011. In other words, big deals were not necessarily a "big value" for libraries and academic stakeholders. Big deals increased serial expenditures to acquire a large number of unused journals. Since big deals also came with annual price increases that often outpaced inflation, serials expenditures skyrocketed, contributing to the current "serials crisis."

The academic publishing market reflects trends predicted by economic theory. Publishers leverage their market power to control prices and increase profits. This market equilibrium favors producers, but it also involves diminished utility for consumers. Comparing with the more competitive markets, the deadweight losses of value and allocative inefficiencies associated with monopoly markets yield lower overall social utility. On the other hand, the profit motive for producers spurs innovation and increased value for consumers. This raises normative questions of whether the high profit rates of large publishers temper the competitive complacency monopolies tend to engender. Continual price increases - and maximization of profits for publishers - in academic journal costs have pushed many universities to their breaking point. With rising journal costs, and often declining state appropriations for higher education, universities are increasingly left with difficult budgetary decisions. These choices occur both within libraries by choosing journals or bundles to cut or retain, as well as via shifting funds from other institutional functions to cover rising library costs.

Escalating cost pressures, in addition to concerns about intellectual property ownership, have spurred resistance against the markets and institutions of academic publish- 
ing from faculty and other university stakeholders. ${ }^{44}$ Examples of this resistance include faculty boycotts of Elsevier (http://www.thecostofknowledge.com), cancellations of big deal bundles with large publishers and "flipping" journals from publisher affiliation to independent open access. ${ }^{45}$ Despite these initiatives, journal costs continue to rise above inflation rates, and profit margins for large publishers remain substantially higher than most other industries. ${ }^{46}$ Scholars need journals to conduct their research and to teach students, so the demand curve for academic journals will be difficult to shift. Demand for core journals is often highly inelastic since they are usually linked to university tenure and promotion systems, as well as representing the scholarly vanguard. Institutional and economic relationships are often path-dependent, so establishing alternative funding models and institutions to the status quo has proved to be difficult. Regardless, challenging big deal bundles offered by publishers may have interesting consequences for secondary journals, which currently often serve as - and are subsidized for- "filler" for these bundled big deals. If stakeholders were able to force or negotiate debundling of journal purchases, a number of secondary journals could be casualties.

\section{Conclusion}

This study shows that the current serials crisis can be attributed to the combination of multiple factors related to the supplier (publishers), the consumer (academic libraries), and the product (journals). With the development of digital technology, electronic journal and online access replaced the print copy and became the dominant format of publishing and accessing academic journals, thus eliminating costs of printing, handling, and shipping. These changes sharply reduced marginal production costs relative to increased sales for producers. Seizing this opportunity, large commercial publishers increased their journal portfolio through mergers, acquisitions, and creating new journals. This allowed them to increase the sales volume of secondary journals through the big deal, making academic publishing one of the most profitable industries in the world. Large publishers have effectively exploited the power of oligopolies. The big deal is often appealing to universities because bundles allow libraries to increase the size of their collection while decreasing the average price per journal. However, as the current study demonstrates, the number of journals cited by the scholars who use these collections did not increase in a similar manner and in actuality, leading the average cost of cited journals to increase. In the end, the big deals are leading many academic libraries into financial difficulties and creating frictions with other library services and stakeholders in universities as library budgets continually expand to keep pace.

As scientific publishing has become one of the most profitable industries in the world, it is perhaps time for libraries, researchers, instructors, students, and university administrators to take a step back and question the current model in which access comes to a price set by corporations and completely disconnected from production costs. Indeed, this study shows that, in the current system, larger serials collections mostly lead to larger expenditures for libraries and bigger profits for publishers, but not to more use. Yes, bigger is better... mostly for publishers.

\section{Notes}

1. Warren O. Hagstrom, The Scientific Community (New York: Basic Books, 1965); Robert K. Merton, The Sociology of Science: Theoretical and Empirical Investigations (Chicago: University of Chicago Press, 1973).

2. Kenneth Frazier, "The Librarians' Dilemma: Contemplating the Costs of the 'Big Deal'," D-Lib Magazine 7, no. 3 (2001), available online at www.dlib.org/dlib/march01/frazier/03frazier. 
html [accessed 5 July 2017]; Judith M. Panitch and Sarah Michalak, The Serials Crisis: A White Paper for the UNC-Chapel Hill Scholarly Communications Convocation (Chapel Hill, N.C.: University of North Carolina, 2005).

3. Panitch and Michalak, The Serials Crisis; Philip Young, The Serials Crisis and Open Access: A White Paper for the Virginia Tech Commission on Research (Blacksburg, Va.: Virginia Tech, 2009); Karla L. Strieb and Julia C. Blixrud, "Unwrapping the Bundle: An Examination of Research Libraries and the 'Big Deal'," portal: Libraries and the Academy 14, no. 4 (2012): 587-615.

4. Narda Tafuri, "Prices of Us and Foreign Published Materials," in Library and Book Trade Almanac, eds. D. Bogart and J.C. Blixrud (Medford, N.J.: Information Today, Inc, 2010), 459-82.

5. Ellie Bothwell, "University of Calgary Cancels Journal Subscriptions," Times Higher Education (Jan. 23, 2017); Strieb and Blixrud, "Unwrapping the Bundle," 587-615; Richard Poynder to Infotoday.com (2011), available online at www.infotoday.com/it/sep11/The-Big-Deal-Not-PriceBut-Cost.shtml [accessed 5 July 2017].

6. Theodore C. Bergstrom, "Free Labor for Costly Journals?" Journal of Economic Perspectives 15, no. 4 (2001): 183-98; Aaron S. Edlin and Daniel L. Rubinfeld, "Exclusive or Efficient Pricing? The Big Deal Bundling of Academic Journals," Antitrust Law Journal 72, no. 1 (2004): 119-57; Carol Tenopir and Donald W. King, "Trends in Scientific Scholarly Journal Publishing in the United States," Journal of Scholarly Publishing 28, no. 3 (1997): 135-70.

7. Bergstrom, “Free Labor for Costly Journals?" 183-98; Theodore C. Bergstrom et al., “Evaluating Big Deal Journal Bundles," Proceedings of the National Academy of Sciences of the United States of America 111, no. 26 (2014): 9425-30; Mathias Dewatripont et al., "Pricing of Scientific Journals and Market Power," Journal of the European Economic Association 5, no. 2/3 (2007): 400-10.

8. Vincent Larivière, Stefanie Haustein, and Philippe Mongeon, "The Oligopoly of Academic Publishers in the Digital Era," PLoS ONE 10, no. 6 (2015): e0127502.

9. William H. Brock, "The Development of Commercial Science Journals in Victorian Britain," in Development of Science Publishing in Europe, ed. A.J. Meadows (Amsterdam: Elsevier Science Publisher, 1980).

10. Paula Kaufman, "Structure and Crisis: Markets and Market Segmentation in Scholarly Publishing," in The Mirage of Continuity: Reconfiguring Academic Information Resources for the 21st Century, eds. B.L. Hawkins and P. Battin (Washington, D.C.: CLIR and AAU, 1998), 178-92.

11. Larivière, Haustein, and Mongeon, "The Oligopoly of Academic Publishers in the Digital Era," e0127502.

12. Mark J. McCabe, "The Impact of Publisher Mergers on Journal Prices: Theory and Evidence," The Serials Librarian 40, no. 1/2 (2001): 157-66.

13. Bergstrom et al., "Evaluating Big Deal Journal Bundles," 9425-30; Hal R. Varian, "Differential Pricing and Efficiency," First Monday 1, no. 2 (1996), available online at www.ojphi.org/ ojs/index.php/fm/article/view/473/829 [accessed 5 July 2017].

14. Edlin and Rubinfeld, "Exclusive or Efficient Pricing? The Big Deal Bundling of Academic Journals," 119-57.

15. Martin Paul Eve to martineve.com (2016), available online at https://www.martineve. com/2016/12/03/referring-elsevierrelx-to-the-competition-and-markets-authority/ [accessed 5 July 2017].

16. Mark Ware and Michael Mabe, "The STM Report: An Overview of Scientific and Scholarly Journal Publishing," (The Hague, Netherlands: International Association of Scientific, Technical and Medical Publishers, 2009).

17. Glenn McGuigan, "Publishing Perils in Academe: The Serials Crisis and the Economics of the Academic Journal Publishing Industry," Journal of Business \& Finance Librarianship 10, no. 1 (2004): 13-26.

18. Frazier, "The Librarians' Dilemma: Contemplating the Costs of the 'Big Deal'."

19. M. Angell and J.P. Kassirer, "The Ingelfinger Rule Revisited," New England Journal of Medicine 325, no. 19 (1991): 1371-73; Carl T. Bergstrom and Theodore C. Bergstrom, "The Economics of Ecology Journals," Frontiers in Ecology and the Environment 4, no. 9 (2006): 488-95; McGuigan, "Publishing Perils in Academe," 13-26.

20. Bergstrom and Bergstrom, "The Economics of Ecology Journals," 488-95; Young, "The Serials Crisis and Open Access."

21. Ian Rowlands and David Nicholas, "Scholarly Communication in the Digital Environment: The 2005 Survey of Journal Author Behaviour and Attitudes," Aslib Proceedings 57, no. 6 (2005): 481-97.

22. Bergstrom, "Free Labor for Costly Journals?" 183-98; Edlin and Rubinfeld, "Exclusive or Efficient Pricing? The Big Deal Bundling of Academic Journals," 119-57; Tenopir and King, "Trends in Scientific Scholarly Journal Publishing in the United States," 135-70; Towards Electronic Journals: Realities for Scientists, Librarians, and Publishers (Washington, D.C.: Special Libraries Association, 2000). 
23. Bergstrom et al., "Evaluating Big Deal Journal Bundles," 9425-30; Paul A. Samuelson and William D. Nordhaus, Economics, 19th ed. (New York: McGraw-Hill, 2010); Varian, “Differential Pricing and Efficiency."

24. Bergstrom and Bergstrom, "The Economics of Ecology Journals," 488-95; Bergstrom et al., "Evaluating Big Deal Journal Bundles," 9425-30; Varian, "Differential Pricing and Efficiency."

25. Edward Chamberlin, The Theory of Monopolistic Competition: A Re-Orientation of the Theory of Value (Cambridge: Harvard University Press, 1962).

26. Bergstrom et al., "Evaluating Big Deal Journal Bundles," 9425-30; Deborah D. Blecic et al., "Deal or No Deal? Evaluating Big Deals and Their Journals," College E Research Libraries 74, no. 2 (2013): 178-94; Dewatripont et al., "Pricing of Scientific Journals and Market Power," 400-10; Enterprise House and Cambridgeshire Histon, "Costs and Business Models in Scientific Research Publishing" (Cambridgeshire, U.K.: The Wellcome Trust, 2004); McGuigan, "Publishing Perils in Academe," 13-26; Ware and Mabe, "The Stm Report: An Overview of Scientific and Scholarly Journal Publishing."

27. Edlin and Rubinfeld, "Exclusive or Efficient Pricing? The Big Deal Bundling of Academic Journals," 119-57; Bergstrom and Bergstrom, "The Economics of Ecology Journals," 488-95.

28. Frazier, "The Librarians' Dilemma: Contemplating the Costs of the 'Big Deal'."

29. Ware and Mabe, "The Stm Report: An Overview of Scientific and Scholarly Journal Publishing."

30. Blecic et al., "Deal or No Deal? Evaluating Big Deals and Their Journals," 178-94.

31. Poynder to Infotoday.com, available online at www.infotoday.com/it/sep11/The-Big-DealNot-Price-But-Cost.shtml [accessed 5 July 2017].

32. McGuigan, "Publishing Perils in Academe," 13-26.

33. Stefanie Haustein, Multidimensional Journal Evaluation: Analyzing Scientific Periodicals Beyond the Impact Factor (Berlin; Boston: De Gruyter/Saur, 2012).

34. S. Baldi, "Normative Versus Social Constructivist Processes in the Allocation of Citations: A Network-Analytic Model," American Sociological Review 63, no. 6 (1998): 829-46; Derek J. de Solla Price, Little Science, Big Science (New York: Columbia Univ. Press, 1963).

35. Eugene Garfield, "To Cite or Not to Cite: A Note of Annoyance," Current Contents 3, no. 35 (1977): 215-18; Robert K. Merton, "The Matthew Effect in Science, Ii: Cumulative Advantage and the Symbolism of Intellectual Property," Isis 79, no. 4 (1988): 606-23.

36. Henk Moed, Citation Analysis in Research Evaluation (Ordrecht, U.K.: Springer, 2005);

37. Philippe Mongeon and Adele Paul-Hus, "The Journal Coverage of Web of Science and Scopus: A Comparative Analysis," Scientometrics 106, no. 1 (2016): 213-28.

38. Frazier, "The Librarians' Dilemma: Contemplating the Costs of the 'Big Deal'."

39. David Leo Weimer and Aidan R. Vining, Policy Analysis: Concepts and Practice (Englewood Cliffs, N.J.: Prentice Hall, 1992). 426.

40. Richard Van Noorden, "The True Cost of Science Publishing," Nature 495, no. 7442 (2013):

41. Larivière, Haustein, and Mongeon, "The Oligopoly of Academic Publishers in the Digital Era," e0127502.

42. Chandra Prabha, "Shifting from Print to Electronic Journals in ARL University Libraries," Serials Review 33, no. 1 (2007): 4-13.

43. Bergstrom et al., "Evaluating Big Deal Journal Bundles," 9425-30; Varian, “Differential Pricing and Efficiency."

44. John Whitfield, "Elsevier Boycott Gathers Pace," Nature (2012), available online at www. nature.com.proxy3.library.mcgill.ca/news/elsevier-boycott-gathers-pace-1.10010 [accessed 5 July 2017].

45. Bothwell, "University of Calgary Cancels Journal Subscriptions"; Q. Schiermeier and E.R. Mega, "Scientists in Germany, Peru and Taiwan to Lose Access to Elsevier Journals," Nature 541, no. 7635 (2016): 13.

46. Bergstrom et al., “Evaluating Big Deal Journal Bundles," 9425-30. 